\title{
IDENTIFIKASI PENGARUH MAKSIMAL LEVEL BEKATUL TERHADAP PENAMPILAN PRODUKSI AYAM PETELUR
}

\author{
Identification Effect of Maximum Level of Rice Bran in Feed on Laying Hen \\ Performance \\ Mohammad Farid ${ }^{1)}$, Eko Widodo ${ }^{2)}$ dan M. Halim Natsir ${ }^{2)}$ \\ 1) Mahasiswa Minat Nutrisi dan Makanan Ternak, Fakultas Peternakan, Universitas Brawijaya Jalan Veteran, \\ Ketawanggede, Kec. Lowokwaru, Kota Malang, Jawa Timur 65145 \\ 2) Dosen Minat Nutrisi dan Makanan Ternak, Fakultas Peternakan, Universitas Brawijaya Jalan Veteran, \\ Ketawanggede, Kec. Lowokwaru, Kota Malang, Jawa Timur 65145 \\ Corresponding email : emhanatsir@ub.ac.id
}

\begin{abstract}
ABSTRAK
Penelitian ini dilaksanakan untuk mengidentifikasi tentang bagaimana pakan yang mengandung bekatul dapat mempengaruhi penampilan produksi ayam petelur. Kandungan serat kasar bekatul sangat tinggi dan bekatul mengandung asam fitat yang merupakan anti nutrisi, sehingga bekatul memiliki batas penggunaan pada level tertentu dalam pakan. Penelitian ini menggunakan 100 ekor ayam petelur betina umur 30 minggu dan bahan pakan perlakuan. Metode yang digunakan adalah percobaan lapang dengan menggunakan empat perlakuan pakan dan masing-masing perlakuan diulang sebanyak 5 kali. Variabel dalam penelitian ini adalah konsumsi pakan, berat telur, hen day production, egg mass, konversi pakan, dan Income Over Feed Cost (IOFC). Metode analisis statistik yang digunakan untuk mengolah data hasil penelitian Rancangan Acak Lengkap (RAL) menggunakan analisis ragam dan uji jarak berganda Duncan. Hasil penelitian menunjukkan bahwa penggunaan bekatul berbagai level dalam pakan tidak memberikan pengaruh nyata $(P>0,05)$ terhadap konsumsi pakan, berat telur, hen day production, egg mass, konversi pakan dan IOFC. Kesimpulan dari penelitian ini adalah bekatul dapat digunakan dengan level tertinggi 30\% dalam pakan dan tidak mempengaruhi perubahan performa produksi ayam petelur.
\end{abstract}

Kata kunci: Bekatul, ayam petelur, penampilan produksi ayam petelur

How to Cite :

Farid, M., Widodo, E., \& Natsir, M. H. (2019). Identifikasi Pengaruh Maksimal Level Bekatul Terhadap Penampilan Produksi Ayam Petelur. Jurnal Nutrisi Ternak Tropis 2 (2) 59-64
*Corresponding author :

M. Halim Natsir

Email : emhanatsir@ub.ac.id

Fakultas Peternakan, Universitas Brawijaya Jalan Veteran, Ketawanggede, Kec. Lowokwaru, Kota Malang, Jawa Timur 65145 


\section{ABSTRACT}

The aim was to know the effects of rice bran levels on laying hen performance. Rice bran contain high crude fiber and also phytic acid as an anti-nutrition, so it has limited level in feed. The material were 100 laying hens of 30 weeks of age. The experiment methods arranged in Completely Randomized Design (CRD) with 4 treatments, each treatment was repeated 5 times. The variables measure were feed consumption, hen day production, egg weight, egg mass, feed conversion, and income over feed cost. The results showed that levels of rice bran didn't significanlty influence $(P>0,05)$ hen day production, egg mass, feed conversion and income over feed cost, amd feed consumption and egg weight. It might be concluded that maximum level of rice bran in laying hen diet was $30 \%$.

Keywords: Rice bran, laying hen, performance.

\section{PENDAHULUAN}

Jawa timur merupakan sentra ayam petelur utamanya di Blitar, peternak yang memelihara ayam petelur umumnya karena pemeliharaan yang mudah, murah dan menguntungkan. Pola pemeliharaan ayam petelur menggunakan pola insentif atau dikandngkan yang diberi pakan sesuai dengan kebutuhan ternak setiap hari. Ayam petelur yang memperoleh nutrisi cukup akan menghasilkan produktivitas tinggi dan berkualitas. Berbagai macam bahan pakan yang umum diberikan pada ayam petelur yaitu bekatul, jagung dan konsentrat.

Jagung memeiliki keunggulan dan kaya energi serta berkaroten tinggi sehingga memberikan warna kuning pekat pada telur, sedangkan kelemahan dari jagung adalah harga yang terikat dengan musim, jika musim panen harga jagung relatif murah namun jika bukan musim panen harga jagung tinggi. Solusinya adalah menggunakan bahan pakan alternatif yang lebih murah misalnya adalah bekatul.

Bekatul merupakan bahan pakan asal hasil samping yang diperoleh dari lapisan luar beras pecah dalam proses terakhir untuk menghasilkan beras, mengandung bagian endosperm dan sedikit bagian kulit pecah gabah yang memiliki kandungan protein $12 \%$, lemak kasar 13\% dan serat kasar 3\% (Sutawi, 2007). Bekatul termasuk pada bahan pakan sumber energi dan memiliki harga yang relatif murah sehingga peternak dalam menambahkan bekatul pada pakan melebihi $40 \%$ karena harapan mampu menekan biaya produksi. Kandungan yang tinggi akan serat kasar serta memiiliki anti nutrisi berupa asam fitat. Asam fitat ini dpat mempengaruhi penyerapan mineral khusunya fosfor didalam saluran pencernaan ayam sehingga akan berdampak pada produksi telur dan menghambat pertumbuhan ternak. Namun pengaruh tersebut belum dapat dipahami oleh peternak karena belum adanya hasil penelitian yang menjelaskan efek penggunaan bekatul dengan level tinggi terhadap performance produksi ternak.

\section{MATERI DAN METODE}

\section{Lokasi dan Waktu Penelitian}

Penelitian ini dilakukan di Deesa Wonorejo, Kecamatan Talun, Blitar. Kandungan nutrisi bahan pakan (Ge, PK, LK, SK, Ca, P, Lisin, Metionin dan Tripsin) dilakukan di Laboratorium Nutrisi dan Makanan Ternak Fakultas Peternakan Universitas Brawijaya Malang.

\section{Materi Penelitian}

Materi yang diguanakan adalah 100 ekor ayam petelur Strain Isa Brown beruumur 30 minggu yang diamati selama 60 hari. Kandang yang digunakan adalah kandang battery yang terbuat dari bambu dengan ukura $25 \mathrm{~cm} \times 35 \mathrm{~cm}$ x $35 \mathrm{~cm}$. Kandungan bahan pakan yang digunakan beserta komposisinya disajikan pada Tabel 1 dan Tabel 2. 
Tabel 1. Kandungan nutrisi bahan pakan penelitian

\begin{tabular}{lccccccccc}
\hline \multicolumn{1}{c}{ Bahan Pakan } & $\begin{array}{c}\text { GE } \\
(\mathrm{Kkal} / \mathrm{kg})\end{array}$ & $\begin{array}{c}\text { PK } \\
(\%)\end{array}$ & $\begin{array}{c}\text { LK } \\
(\%)\end{array}$ & $\begin{array}{c}\text { SK } \\
(\%)\end{array}$ & $\begin{array}{c}\text { Ca } \\
(\%)\end{array}$ & $\begin{array}{c}\text { P } \\
(\%)\end{array}$ & $\begin{array}{c}\text { Lis } \\
(\%)\end{array}$ & $\begin{array}{c}\text { Met } \\
(\%)\end{array}$ & $\begin{array}{c}\text { Trip } \\
(\%)\end{array}$ \\
\hline Jagung & 4276,22 & 8,950 & 4,940 & 3,180 & 0,02 & 0,28 & 0,26 & 0,18 & 0,06 \\
Bekatul & 3538,89 & 9,350 & 13,69 & 12,83 & 0,05 & 1,31 & 0,57 & 0,22 & 0,13 \\
Bungkil kedelai & 2944,12 & 47,93 & 2,490 & 4,480 & 0,29 & 0,65 & 2,69 & 0,62 & 0,74 \\
MBM & 3571,65 & 46,08 & 11,60 & 2,720 & 10,0 & 5,10 & 2,61 & 0,69 & 0,27 \\
PMM & 4471,67 & 62,18 & 11,78 & 0,880 & 3,00 & 1,70 & 3,10 & 0,99 & 0,37 \\
\hline
\end{tabular}

Sumber: Hasil analisi proksimat di Laboratorium Nutrisi dan Makanan Ternak Fakultas Peternakan, Universitas Brawijaya Malang.

Tabel 2. Bahan Pakan yang digunakan selama penelitian

\begin{tabular}{lcccc}
\hline \multirow{2}{*}{ Bahan Pakan } & \multicolumn{4}{c}{ Persentase (\%) } \\
\cline { 2 - 5 } Jagung & $\mathrm{P}_{1}$ & $\mathrm{P}_{2}$ & $\mathrm{P}_{3}$ & $\mathrm{P}_{4}$ \\
Bekatul & 54,39 & 44,46 & 34,53 & 24,6 \\
Bungkil kedelai & 10,00 & 20,00 & 30,00 & 40,00 \\
Meat and Bone Meal & 15,14 & 15,07 & 15,00 & 14,93 \\
Poultry Meat Meal & 5,00 & 5,00 & 5,00 & 5,00 \\
Tepung Batu & 3,00 & 3,00 & 3,00 & 3,00 \\
Minyak Kelapa & 8,38 & 8,38 & 8,38 & 8,38 \\
DL-Metionin & 3,00 & 3,00 & 3,00 & 3,00 \\
L-Lisin & 0,20 & 0,20 & 0,20 & 0,20 \\
Sel-plex & 0,25 & 0,25 & 0,25 & 0,25 \\
Premix & 0,03 & 0,03 & 0,03 & 0,03 \\
Kandungan Nutrisi & 0,61 & 0,61 & 0,61 & 0,61 \\
Energi Metabolis (Kkal/kg)* & & & & \\
PK (\%)* & 2739 & 2703 & 2689 & 2675 \\
SK (\%)* & 18 & 18 & 18 & 18 \\
LK (\%)* & 2,76 & 2,89 & 3,11 & 3,53 \\
Ca (\%)* & 4,18 & 4,99 & 6,14 & 8,22 \\
P (\%)** & 3,51 & 3,52 & 3,54 & 3,55 \\
Lisin (\%)** & 0,67 & 0,79 & 0,91 & 1,01 \\
Metionin (\%)** & 1,12 & 1,15 & 1,15 & 1,16 \\
Ketangan * kand & 0,66 & 0,67 & 0,67 \\
\hline
\end{tabular}

Keterangan:* kandungan nutrisi berdasarkan perhitungan yang mengacu pada analisis proksimat bahan pakan

** kandungan nutrisi berdasarkan perhitungan yang mengacu pada tabel NRC (1994).

Tabel 3. Rataan hasil konsumsi pakan, HDP, Berat Telur, Egg mass, konversi pakan dan IOFC selama penelitian.

\begin{tabular}{lcccc}
\hline Variabel & \multicolumn{4}{c}{ Perlakuan } \\
\cline { 2 - 5 } & $\mathrm{P}_{1}$ & $\mathrm{P}_{2}$ & $\mathrm{P}_{3}$ & $\mathrm{P}_{4}$ \\
\cline { 2 - 5 } Konsumsi pakan (g/ekor) & $117,8 \pm 1,50$ & $116,35 \pm 1,25$ & $116,48 \pm 1,14$ & $117,5 \pm 0,49$ \\
HDP (\%) & $79,36 \pm 10,46$ & $76,50 \pm 9,26$ & $76,57 \pm 6,50$ & $66,89 \pm 2,43$ \\
Berat telur (butir) & $60,74 \pm 1,81$ & $61,56 \pm 1,51$ & $61,06 \pm 2,67$ & $61,77 \pm 2,71$ \\
Egg mass (g) & $48,05 \pm 5,28$ & $47,02 \pm 5,66$ & $46,66 \pm 2,63$ & $41,24 \pm 1,39$ \\
Konversi Pakan & $2,49 \pm 0,27^{\mathrm{a}}$ & $2,48 \pm 0,27^{\mathrm{a}}$ & $2,58 \pm 0,15^{\mathrm{a}}$ & $2,89 \pm 0,15^{\mathrm{b}}$ \\
IOFC (Rp) & $175.04 \pm 61.35$ & $177.70 \pm 66.54$ & $184 \pm 30.66$ & $127 \pm 17.01$ \\
\hline
\end{tabular}

Keterangan $=\mathrm{a}-\mathrm{b}$ dalam baris yang sama menunjukkan perbedan yang nyata $(\mathrm{P}<0,05)$ 


\section{Metode Penelitian}

Penelitian ini menggunakan metode percobaan dengan Rancangan Acak Lengkap (RAL) terdiri dari 4 perlakuan dan masing-masing perlakuan diulang sebanyak 5 kali. Masing-masing unit percobaan terdiri dari 5 ekor ayam sehingga total ada 100 ekor ayam yang digunakan. Perlakuan yang digunakan. Berikut ini adalah komposisi perlakuan pakan dalam penelitian ini :

$\mathrm{P}_{1}$ : Pakan basal yang mengandung $10 \%$ bekatul

$\mathrm{P}_{2}$ : Pakan basal yang mengandung $20 \%$ bekatul

$\mathrm{P}_{3}$ : Pakan basal yang mengandung $30 \%$ bekatul

$\mathrm{P}_{4}$ : Pakan basal yang mengandung $40 \%$ bekatul

\section{Variabel Penelitian}

Variabel yang diukur yaitu :

1. Konsumsi pakan (g/ekor/hari) adalah rata-rata pakan yang mampu dikonsumsi oleh seekor ayam selama penelitian berlangsung yang diukur setiap hari (Marhiyanto, 2004)

2. Hen Day Production adalah produksi telur harian yang dihitung setiap hari dengan satuan \% (Kurniawan, 2001)

HDP $=\frac{\sum \text { Produksi telur hari itu (butir) }}{\Sigma \text { ayam yang ada }} \times 100 \%$

3. Berat telur merupakan berat satu butir rataan dalam datu. Satuan berat telur adalah butir.

4. Egg mass adalah berat telur rata-rata per hari per ayam.

5. Konversi pakan merupakan angka yang menunjukkan kemampuan ternak untuk mengubah sejumlah pakan menjadi setiap $\mathrm{kg}$ produksi. Konversi ini menunjukkan efisiensi penggunaan pakan ditunjau dari efisiensi teknis. Konversi pakan dihitung setiap minggu.

Konversi pakan $=\frac{\text { konsumsi pakan }(\mathrm{kg})}{\text { produksi telur total }(\mathrm{kg})}$
6. Income Over Feed Cost (IOFC) yang merupakan pendapat setelah dikurangi dengan biaya pakan (Herwintono, 2001).

Data hasil penelitian ini selanjutnya dianalisis menggunakan analisis ragam dalam Rancangan Acak Lengkap (RAL), apabila ada perbedaan dilakukan Uji Jarak Berganda Duncan's.

\section{HASIL DAN PEMBAHASAN}

Data hasil perlakuan penambahan bekatul terhadap variabel disajikan pada Tabel 3.

\section{Konsumsi Pakan}

Tabel 3. Menunjukkan bahwa nilai konsumsi pakan tertinggi pada P1 (117,8 \pm 1,50) dan terendah P2 (116,35 $\pm 1,25)$. Penambahan bekatul berbagai level dalam pakan tidak berpengaruh nyata $(\mathrm{P}>0,05)$ terhadap konsumsi pakan ayam petelur. Adapun konsumsi dipengaruhi oleh beberapa faktor yaitu kandungan energi pakan, serat kasar dan lemak kasar.

Penurunan energi metabolis pakan dari $2739 \mathrm{Kkal} / \mathrm{kg}$ untuk level bekatul terendah yaitu $10 \%$ menjadi $2675 \mathrm{Kkal} / \mathrm{kg}$ untuk level pemberian bekatul tertinggi yaitu $40 \%$ masih dapat ditoleransi mengingat ayam petelur biasanya diberikan pakan secara terbatas. Hal ini sesuai dengan Standard (SNI) bahwa kebutuhan minimal energi metabolis untuk ayam petelur adalah $2650 \mathrm{Kkal} / \mathrm{kg}$ (BSN, 2006). Serat kasar dalam pakan yang tinggi akan menurunkan konsumsi pakan.

Kandungan serat yang tinggi dalam pakan ayam dapat menunrunkan tingkat konsumsi ayam karena serat kasar dalam pakan ayam dibutuhkkan dalam jumlah yang rendah. Dalam perlakuan pakan kandungan serat kasar dapat digolongkan rendah antara 2,76 - 3,53\% dan masih sesuai dengan batas maksimal menurut SNI adalah 7\% (BSN, 2006). 


\section{Hen Day Production (HDP)}

Berdasarkan hasil penelitian yang tertera di Tabel 3 menunjukkan nilai tertinggi HDP adalah P1 ( 79,36 $\pm 10,46 \%)$ dan terendah P4 $(66,89 \pm 2,43 \%)$. Hasil tersebut dilanjutkan dengan analis data statistika menunjukkan tidak ada perbedaan yang nyata $(\mathrm{P}>0,05)$ terhadap HDP ayam petelur. Produksi telur sangat dipengaruhi oleh jumlah dikonsumsi pakan dan kandungan nutrisi dalam pakan (Amrullah, 2003). Data konsumsi pakan yang telah disajikan dalam Tabel 3 tidak menunjukkan perbedaan yang nyata sehingga produksi telur juga tidak berbeda nyata antar perlakuanm namun secara numerik ada kecenderungan bahwa dengan semakin tinggi level bekatul dalam pakan maka dapat menurunkan HDP.

\section{Berat Telur}

Tabel 3. Menunjukkan bahwa berat telur terendah terdapat pada $\mathrm{P} 1(60,74 \pm 1$, $181 \mathrm{~g})$ dan yang tertinggi adalah P4 $(61,77 \pm$ 2,71). Berat telur ayam sudah sesuai dengan pendapat Srigandono (1992) yang menyatakan bahwa telur ayam beratnya sekitar 55-60 g. Hasil dari analisis statistika menunjukkan pengaruh yang tidak berbeda nyat $(\mathrm{P}>0,05)$ terhadap berat telur. Penelitian ini tingkat penggunaan $40 \%$ bekatul dalam pakan mengandung lemak kasar $8,22 \%$ dan paling tinggi bila dibandingkan dengan kandungan lemak kasar pada perlakuan lain sehingga berat telur P4 menunjukkan rataan yang paling tinggi. Sohail, et al (2003) menyatakan bahwa adanya pengaruh nyata terhadap kandungan lemak yang tinggi dengan berat telur.

\section{Egg mass}

Nilai egg mass yang tertera pada Tabel 3. Menunjukkan nilai tertinggi dari perlakuan P1 $(48,05 \pm 5,28 \mathrm{~g})$ dan nilai terendah dari $\mathrm{P} 4(41,24 \pm 1,39 \mathrm{~g})$. Hasil statistika menunjukkan pengaruh yang tidak nyata $(P>0,05)$ terhadap egg mass ayam petelur. Egg mass merupakan rataan berat telur harian, sehingga persentase HDP mempengaruhi egg mass. Amrullah (2004) menyatakan bahwa penggunaan variabel egg mass dibandingkan jumlah berat telur merupakan cara menyatakan perbandingan kemampuan produksi bertelur antar kelompok unggas akibat pemberian pakan dan program pengelolaan yang baik. Dalam penelitian ini, berat telur yang cenderung sama tetapi HDPnya secara numerik cenderung menurun mengakibatkan egg mass ayam petelur yang semakin menurun.

\section{Konversi Pakan}

Tabel 3. Menunjukkan bahwa konversi pakan tertinggi terdapat pada perlakuam P4 $(2,89 \pm 0,15 \mathrm{~g})$ dan nilai terendah P2 (2,48 $\pm 0,27 \mathrm{~g})$. Hasil analisis statistika menunjukkan pengaruh yang berbeda nyata $(\mathrm{P}<0,05)$ terhadap konversi pakan dan P2 adalah perlakuan pakan yang paling efisien terlihat dari nilai konversi pakan yang terkecil. Ketaren (2002) menyatakan bahwa buruknya efisiensi penggunaan pakan pada ayam petelur diakibatkan oleh berbagai faktor termasuk genetik, banyaknya pakan yang bercecer dan kandungan gizi pakan yang tidak sesuai dengan kebutuhan.

\section{Income Over feed Cost}

Tabel 3 menunjukkan bahwa IOFC tertinggi didapat dari P1 (Rp. $175.04 \pm$ 61,35) dan yang terendah dari P4 ( Rp. 127 \pm 17.07), sedangkan hasil statistik menunjukkan bahwa pemberian beberapa level bekatul dalam pakan ayam memberikan pengaruh yang tidak berbeda nyata $(\mathrm{P}<0,01)$ terhadap IOFC. Adanya kecenderungan penurunan dan peningkatan konsumsi pakan dan konversi pakan dengan perlakuan ini dapat memberikan pengaruh terhadap IOFC. Secara numerik penggunaan bekatul dalam pakan hingga 30\% akan memberikan IOFC yang semakin tinggi. Hal ini dapat terjadi karena konsumsi pakan ayam antar perlakuan cenderung sama namun terjadi perbedaan pada nilai HDP.

Harga total pakan yang digunakan dalam perlakuan P1 lebih mahal dibandingkan dnegan perlakuan lainnya 
yaitu Rp. 3.421.23/kg dan perlakuan P4 yang paling murah Rp. 3.124./kg. Namun dari hasil analisis statistika ternyata IOFC tertinggi didapat dari P3, hal ini dikarenakan pakan P3 dengan konsumsi pakan rendah namun produksi telur pada P3 juga lebih tinggi. Pemberian pakan murah pada ayam harus memperhatikan kualitas pakan karena akan berdampak pada produktivitas ternak, karena apabila pakan yang diberikan murah belum tentu dapat meningkatkan keuntungan peternak (Ranto, 2005).

\section{KESIMPULAN DAN SARAN}

Hasil penelitian ini dapat menyimpulkan bahwa pemberian bekatul dapat digunakan dalam pakan ayam petelur sampai level 30\% tanpa mempengaruhi penampilan produksi. Konsumsi pakan, HDP, berat telur, egg mass, konversi pakandan IOFC ayam petelur.

\section{DAFTAR PUSTAKA}

Amrullah, I. (2004). Nutrisi Ayam Petelur. Jakarta: Penebar Swadaya.

Herwintono, \& Kurniawati, Y. E. (2001). Pengaruh penggunaan tepung jnagkrik dalam ransum terhadap konsumsi pakan, konversi pakan dan income over feed cost pada burung puyuh fase layer. Jurnal Protein, 17, 1013-1019.
Ketaren, P. (2002). Kebutuhan gizi itik petelur dan itik pedaging. Jurnal Wartazoa, 12(2), 37-46.

Kurniawan, H. K. (2001). Pengaruh Tingkat Pemberian Campuran Onggok dan Kotoran Ayam Kering Difermentasi Rhizopus sp dalam pakan terhadap penampilan Produksi Itik Petelur. Universitas Brawijaya.

Marhiyanto, B. (2004). Beternak Bebek Darat Petelur. Surabaya: Gitamedia Press.

NRC. (1994). Nutrient Requirement of Poultry (9th ed.). Washington, D.C: National Academic Press.

Ranto, \& Sitanggang, M. (2005). Panduan Lengkap Beternak Itik. Jakarta: Agromedia Pustaka.

Srigando, B. (1992). Produksi Ternak Air. Yogyakarta: Gadjah Mada University Press.

Sutawi. (2007). Kapita Selekta Agribisnis Peternakan. Malang: Universitas Muhammadiyah Malang Press. 